\title{
The Impact of Citizen Satisfaction with Government Performance on Public Trust in the Government: Empirical Evidence from Urban Yemen
}

\author{
Mona Salim*, Xiaobao Peng, Shoqi Almaktary, Saleem Karmoshi \\ The School of Public Affairs, University of Science and Technology of China, Hefei, China \\ Email: *monabas@mail.ustc.edu.cn
}

How to cite this paper: Salim, M., Peng, X.B., Almaktary, S.Q. and Karmoshi, S. (2017) The Impact of Citizen Satisfaction with Government Performance on Public Trust in the Government: Empirical Evidence from Urban Yemen. Open Journal of Business and Management, 5, 348-365. https://doi.org/10.4236/ojbm.2017.52030

Received: January 20, 2017

Accepted: April 27, 2017

Published: April 30, 2017

Copyright $\odot 2017$ by authors and Scientific Research Publishing Inc. This work is licensed under the Creative Commons Attribution International License (CC BY 4.0).

http://creativecommons.org/licenses/by/4.0/

\begin{abstract}
Until now, there have been no empirical studies published investing the link between citizens' satisfaction with government performance and its impact on public trust towards the government. Here, we explore the case of the Yemeni government. Public trust in government is considered very low among Arabic countries. Public trust in government in Yemen was found to be much lower than expected. Furthermore, the variables of citizen satisfaction with the quality of public services, the transparency of government and government performance in fighting corruption were found to be positively associated with public trust in the transitional Yemeni government at both the city and central levels. This study also found that some demographic features in Yemeni citizens such as males with low and middle school education showed a higher possibility of trust in city government. These findings suggest that maintaining political trust will be a challenge for the transitional Yemeni government especially because Yemen is now experiencing civil war.
\end{abstract}

\section{Keywords}

Citizens' Satisfaction, Corruption, Public Services, Transparency, Transitional Government

\section{Introduction}

Governments that enjoy greater levels of public trust can function more easily and effectively than those with less public trust [1] In this context, trust may be considered to occupy a key role in making governments operate correctly [2]. [3] as well as [4] found that the citizens' degree of trust in government was in- 
fluenced by levels of satisfaction with government performance. This serves as a logical extension of the factors that were laid out by [5] Thus, it is often assumed that a decline of trust in government may be, at least in part, tied to lower levels of citizen satisfaction [3] [6] [7].

The absence of trust in government generally creates citizens who do not want to pay taxes, and who do not obey the law... and makes necessary an increase in the number of monitoring and enforcement systems [8]. These consequences are very obvious when we examine the current Yemeni status. The Yemeni government's poor performance could be one of many reasons which caused a citizens revolution against the government in 2011. After that, things got more complicated and Yemen now ends up in a situation of Civil war. Until this moment, this has been no survey used to examine the correlation between public trust in the Yemeni government and the citizens' satisfaction with government performance. Therefore, this research paper provides a unique contribution to the literature on public trust in government by studying the case of Yemen.

One of this paper objectives is to provide clear insights about the citizen satisfaction with government performance and its impact public trust in Yemeni government. Which provide an example of public trust in government of a country raged with civil war and divided into two governments, such studies are rare or never been conducted in this part of the world, thus this study provides clear insights of citizen satisfaction with performance in this part of the world. Therefore, this study is trying to answer an important question about how citizens respond to good or bad government performance, particularly during transitional periods of government life, with respect to their satisfaction judgments and, in turn, their overall trust in government.

\section{Background about Yemen's Government Status}

Before starting explaining how citizen satisfaction could impact the public trust in government, we wanted to provide clear insights about the Yemeni government's status. This could be considered a unique status by comparing other countries around the world. In March 2015, the Kingdom of Saudi Arabia and a coalition of Arab allies started a series of air strikes against Houthi targets in Sana'a, Aden, and other regions of Yemen. This was related to an ongoing conflict between pro-government forces backed by the Saudi-led coalition, and Houthi militias allied with units of the armed forces faithful to former President Ali Abdullah Saleh. It looked as though the Houthis and their allies would continue to control Sana'a, the northern regions that border Saudi Arabia along the Red Sea. Meanwhile president Hadi's government is currently based in Aden.

That's exactly what's happening in Yemen right now. From the public's viewpoint in Sana'a, the transitional government cannot be trusted, nor can much of the international donor and development community. This is a severe problem and could collapse of tenuous transitional roadmaps unless course-corrected instantly. Consider Yemen's government. The transitional government frequently claims no responsibility for the provision of basic services to nearly 25 million 
citizens in Yemen, despite the fact that the majority's basic security needs are desperate and they are sitting dangerously on the precipice of a collapse.

The lack of trust comes with severe consequences: Yemeni citizens won't be paying taxes anytime soon. Their justification makes sense. Why give the transitional government money if it's wholly corrupt and can't take care of its population? There's little public motivation to pay taxes when Yemeni citizens won't see that money returned through clean water and sanitation, infrastructure, or economic development.

\section{Literature Review and Hypotheses}

The research focused on trust in government. This is often considered as confidence in government, or political trust [9]. According to [10], the public trust in government can be evaluated by the extent to which citizens have confidence in the government to operate in the best interests of society. [11] defined trust in government as an evaluation of whether or not the government is performing in accordance with normative expectations held by the public. [12] first defined the types of trust in government as being specific and diffuse. The specific type refers to satisfaction with government outputs and the overall performance of political authorities. Meanwhile, diffuse refers to the public's attitude toward regime-level political objects, regardless of their performance. Specific support encloses the economic value of the exchange between citizen and government, while diffuse support encapsulates the fundamentals.

No government can enjoy the absolute trust of its citizens because the power of any government represents a threat to individual freedom and welfare [13]. Notwithstanding this affirmation, government should have a minimum level of confidence from its citizens to operate effectively. Trust is fundamentally important for a healthy and functioning democracy [14]. It engenders citizen compliance with public policies, encourages political participation, and contributes to perceptions of governmental legitimacy [15].

Due to the lack of literature about the public trust in the Arab world, and especially Yemen, this research discusses the determinants of public trust in government at both the local and central levels. This is done order to provide empirical evidence from a developing country like Yemen which has experienced a citizens' revolution against its government and political leadership.

\section{Citizen Satisfaction with the Quality of Public Services and Public Trust in Government}

Satisfaction with the quality of public services is also known as citizen satisfaction with public service delivery. It can be defined as citizens' perception of the quality of the goods and services that are provided by the government. This includes such things as primary education and public health [7] [16] [17]. The measurements of satisfaction with the quality of public services in previous studies have shown that the core element of the definition is citizens' perception of the specific public services that are delivered by the government. It also includes 
the specific public services that often vary between countries or regions. Therefore, the definition of citizens' satisfaction with the quality of public services can be inferred to be citizens' perceptions concerning the specific public services delivered by the local and central governments.

Based on the above information, the definition of satisfaction with the quality of public services in Yemen can be interpreted as Yemeni citizens' perceptions about the specific public services delivered by the local and central government. The specific items of public service delivery are considered based on Yemen's own realities. [18] maintain that the causal relationship between satisfaction with the quality of public services and trust in government is often contested. However, many other scholars [19] [20] have demonstrated that citizen satisfaction with the quality of public services is a key determinant of citizen trust in government.

In addition, other scholars [4] [21] [22] [23] [24] [25] have demonstrated that citizen satisfaction with the quality of public services is positively associated with citizen trust in government. In this way, this current study tests the following hypothesis:

H1: Citizen satisfaction with the quality of public services is positively associated with trust in city government inside Yemen (H1a), and trust in the central government of Yemen (H1b).

\section{Citizen Satisfaction with the Government's Transparency and Trust in Government}

Transparency is normally defined as the open flow of information [26]. A government's transparency is dependent on the quantity and quality of information transferred between the government and citizens. It also involves the improvement of the information distribution system, and literature on transparency in the relationship between governments and citizens has strongly highlighted the perception of openness. In the past, many governments around the world passively provided information only upon request, and they did so according to their own will. Now, many are being required to engage in more active disclosure.

The sharply growing request for transparency is based on many factors. First, transparency is one of the central moral claims inside democratic societies. Here, the people's right to have access to government information is being widely accepted within representative democracies [27]. Secondly, transparency is one of the practical measures taken to limit corruption, acting as a restraint against corrupt behavior by promoting citizen's vigilance, and thus deterring public officials from misusing public services to attain private gain [28]. [5] has observed that this can serve as a strategy to deter corruption and correct poor performance. Third, transparency has a positive effect on trust and accountability [29]. According to [30], transparency is linked with the values of accountability, "as it allows citizens to monitor the quality of public services and encourages public employees to satisfy citizens". However, some scholars urge caution, citing the 
negative aspects of transparency, such as violations of privacy, direct costs of disclosure, and revelation of sensitive information [31].

[32] according this article it has confirmed the positive relationship between trust in government and the transparency of government through the introduction of service charter experience in Spain. The following hypotheses will also be tested by this study:

H2: Citizen Satisfaction with the transparency of government is positively associated with trust in the central government in Yemen (H2a), and trust in city governments of Yemen (H2b).

\section{Citizen Satisfaction with Government Efforts at Fighting Corruption and Trust in Government}

Corruption occurs as a form of behavior which violates the official ethics of public service. It can occur in the private sector or in the public sector and mostly occurs together [33]. One of the most cited definitions of corruption is provided by [34] who defines it as: "behavior which deviates from the formal duties of a public role because of private regarding (personal, close family, private clique) financial or status gains; or violates rules against the exercise of certain types of private-regarding influence". Other scholars like [35] define corruption in a more detailed way as acts containing three elements: violations of law, rules, regulations, or ethical values; misuse of an officer's position; and taking of some actual or expected material reward or gain. The impact of corruption, regardless of its form, undermines the performance of the public services and decreases satisfaction with them. This is neatly captured in [36] description of corruption as "a sign that something has gone wrong in the management of the state".

Combating corruption is instrumental to the wider goal of achieving a more effective, fair, and efficient government. When there is insufficient transparency, accountability, and public awareness about the use of public resources, the state fails to create authority and credibility. Systemic corruption undermines the credibility of democratic institutions and counteracts good governance. There is a high correlation between corruption and the absence of respect for human rights, and between corruption and undemocratic practices. Essentially, corruption isolates citizens from their government.

The following hypothesis will be tested by this study:

H3: Citizen satisfaction with government efforts at fighting corruption is positively associated with trust in the central government of Yemen (H3a) and with public trust in city government of Yemen (H3b).

\section{Method}

This research study collected data using two methods: first by sending online surveys to people who had the ability to access the internet; and second, by meeting residents randomly and asking them to complete the survey. When the respondent agreed to contribute to this survey, the researcher would collect the completed survey, and increase the highest possible completion rate. The ques- 
tionnaire was covered by a letter, which contained a brief introduction about the purpose of the survey. The random sampling method was to select respondents who were older than 18 years old. The data collection was conducted between September and October in 2016. The survey covered respondents whom were living in urban areas, and who were also under the control of the transitional Yemeni government. The sampling number of respondents who agreed to be enrolled in the survey was 450 . We deleted cases where data was missing and thereby obtained a total of 420 responses. The characteristics of the respondents are shown in Table 1.

\section{Dependent Variable}

The dependent variable of this study is public trust in the government of Yemen. It was measured by one scale which has two items for measuring public trust in both levels, one item for central government and one item for local government, the measurement for public trust in government in both levels through the following question: "Please indicate to what extent you trust the public institutions [the city government, the central government] to always do the right thing for the people on a scale from 1 (Not trust it at all) to 7 (Trust it to very high extent)" [23].

Table 1. Description of dependent and demographic variables.

\begin{tabular}{|c|c|c|c|}
\hline Variable & $\begin{array}{c}\text { Percentage } \\
(\%)\end{array}$ & Variable & $\begin{array}{c}\text { Percentage } \\
(\%)\end{array}$ \\
\hline Trust in central government & & Gender & \\
\hline Not trust it at all & 61.7 & Male & 51.7 \\
\hline Highly distrust it & 17.9 & Female & 48.3 \\
\hline Not trust it & 9.5 & Age(year) & \\
\hline Neutral & 5.2 & $18-29$ & 60.5 \\
\hline Trust it & 3.6 & $30-49$ & 34 \\
\hline Highly trust it & 1.2 & $50-69$ & 5.5 \\
\hline Trust it to very high extent & 1 & $\begin{array}{c}\text { Income (us dollar) } \\
\text { monthly }\end{array}$ & \\
\hline Trust in city government & & Zero - 199.99 & 60.7 \\
\hline Not trust it at all & 68.1 & $200-399.99$ & 10 \\
\hline Highly distrust it & 15.2 & $400-599.99$ & 9 \\
\hline Not trust it & 6.7 & $600-899.99$ & 2.9 \\
\hline Neutral & 2.9 & $900-109.99$ & 6.9 \\
\hline Trust it & 3.1 & 1200 and above & 10.5 \\
\hline Highly trust it & 1.4 & Education & \\
\hline \multirow[t]{4}{*}{ Trust it to very high extent } & 2.6 & $\begin{array}{l}\text { Middle school and } \\
\text { below }\end{array}$ & 7.3 \\
\hline & & High school & 19.8 \\
\hline & & Junior college & 14.5 \\
\hline & & $\begin{array}{c}\text { Bachelor degree } \\
\text { and above }\end{array}$ & 58.1 \\
\hline
\end{tabular}




\section{Independent Variables}

In this research project, there are three independent variables for measuring citizens' satisfaction with the following:

- The quality of public services provide by the transitional Yemeni government

- The government effort in fighting corruption

- The transparency of the government

The survey consisted of three scales for measuring citizen satisfaction with (anti-corruption, public services, and transparency) totaling 18 items. Each item represented a statement to which participants were invited to respond on a Seven-point Likert-scale, where "strongly agree" was coded as 7 and "strongly disagree" was coded as 1 .

\section{Test for Reliability and Validity of Search Variables}

The first independent variable of this study was citizen satisfaction with the quality of public services. It was measured through 9 items using the total items Cronbach's Alpha $=0.887$ shown in Appendix Table 1S.

The second independent variable of this study was citizen satisfaction with government effort in fighting corruption within the public sector. It was measured using five items, using the total items Cronbach's Alpha $=0.925$. The scale has been shown as an Appendix in Table 2S.

The third independent variable of this study was citizen satisfaction with government transparency. It was measured using five items with Total items Cronbach's Alpha $=0.886$. The questions for measuring government transparency have been shown in Table 3S.

All the study variables have reliability value Cronbach's Alpha $>0.7$, this is indicated these variables are considered statically reliable variables for investigating the study hypotheses.

\section{Confirmatory Factor Analysis of Search Items}

For a reduction in the number of items for measuring citizen satisfaction with the quality of public services, we subjected a principal components analysis (PCA). (PCA) exposed the presence of two components with eigenvalues exceeding 1, explaining 53.24 per cent and 11.699 per cent of the variance, respectively. When checking the scree plot, it was revealed that there was a clear break after the second component. We used [37] scree test, and decided to keep two components for further investigation.

The two component solution explained a total of $64.82 \%$ of the variance, with Component 1 contributing 53.24\% and Component 2 contributing 11.64\%. Since the contribution of second factor was considered low with a value of $11.64 \%$ and this factor only represented one item of the nine items, for representing public services through factors, we used one factor Fp1. The factors and eigenvalues of Fp1 and Fp2 have shown as Appendix Table 4S.

Meanwhile, there were 5 items for measuring satisfaction with government effort against corruption, we did confirmatory factor analysis which revealed the 
presence of one component with an eigenvalue exceeding 1, explaining 77.488 per cent of the variance. Therefore for representing the 6 items for measuring citizen satisfaction with government transparency through one factor Fc2. This has been shown in Appendix Table 5S.

We did the same procedures with 6 items for measuring citizen satisfaction with government effort against corruption using a principal components analysis (PCA) which also revealed the presence of one component with an eigenvalue exceeding 1 . This was useful for explaining 65.504 per cent of the variance. The 6 items for citizen satisfaction with government transparency were represented through one factor FT3. This has been shown in Appendix Table 6S.

\section{Results}

For examining the research hypotheses, we did Spearman's Rho Correlations between the study variables, (FP1) represented citizen satisfaction with the quality of public services, (FC2) represented citizen satisfaction with government effort in fighting corruption, (FT3) represented citizen satisfaction with government transparency, (T1) represented trust in the central government, and (T2) represented trust in the city government. This has been shown in Table 2.

The results indicated a fairly strong correlation between citizen satisfaction with public services (FP1) and citizen satisfaction with government effort against corruption (FC2) $(r=0.688, p<0.001)$. There was also a strong positive correlation between the satisfaction with public services (FP1) and the satisfaction with government transparency (FT3) $(r=0.697, \mathrm{p}<0.01)$. The results also point out that there was a strong positive relation between satisfaction with government transparency (FT3) and satisfaction with government efforts against corruption (FC2) $(\mathrm{r}=0.694, \mathrm{p}<0.01)$.

Meanwhile the results showed a high positive correlation between public trust in the central government (T1) with the citizen satisfaction with public services

Table 2. Spearman's Rho correlations.

\begin{tabular}{|c|c|c|c|c|c|}
\hline & FP1 & FC2 & FT3 & $\mathrm{T} 1$ & $\mathrm{~T} 2$ \\
\hline $\begin{array}{l}\text { Citizen satisfaction with } \\
\text { the quality of public } \\
\text { services (FP1) }\end{array}$ & 1.000 & & & & \\
\hline $\begin{array}{l}\text { Citizen satisfaction with the } \\
\text { government efforts against } \\
\text { corruption FC2 }\end{array}$ & $0.688^{* *}$ & 1.000 & & & \\
\hline $\begin{array}{l}\text { Citizen satisfaction with } \\
\text { the government } \\
\text { transparency FT3 }\end{array}$ & $0.697^{\star *}$ & $0.694^{* *}$ & 1.000 & & \\
\hline $\begin{array}{c}\text { Trust in central } \\
\text { government }(\mathrm{T} 1)\end{array}$ & $0.540^{\star *}$ & $0.558^{\star *}$ & $0.558^{\star *}$ & 1.000 & \\
\hline $\begin{array}{c}\text { Trust in city } \\
\text { government (T2) }\end{array}$ & $0.422^{\star *}$ & $0.484^{* *}$ & $0.459^{\star *}$ & $0.614^{\star *}$ & 1.000 \\
\hline
\end{tabular}

${ }^{*} \mathrm{p}<0.05 .{ }^{* *} \mathrm{p}<0.01 .{ }^{* *} \mathrm{p}<0.001$; two tailed tests. 
(FP1) $(\mathrm{r}=0.540, \mathrm{p}<0.01)$. There was also the same high correlation between (T1) and satisfaction with government efforts in fighting corruption (FC2) $(r=$ $0.558, \mathrm{p}<0.01)$, respectively, and (T1) satisfaction with government transparency (FT3) $(r=0.558, p<0.01)$. The correlation results indicate that when citizens showed high satisfaction with these three independent variables (FP1, FC2, and FT3), this was also associated with high trust in the central Yemeni government.

Furthermore the results indicated that there are positive correlation between public trust in the city government and satisfaction with the three independent variables of this research, for instance there is strong positive correlation between public trust in the city government (T2) and satisfaction with public services (FP1) $(\mathrm{r}=0.422, \mathrm{p}<0.01)$. Also there is strong positive correlation the satisfaction with government efforts against corruption (FC2) and (T2) $(r=0.484$, $\mathrm{p}<0.01)$. We found that the correlation between satisfaction with government transparency (FT3) and (T2) is the highest positive correlation among the three independent variable with value $(r=0.459, \mathrm{p}<0.01)$.

The results indicated that there is very strong positive correlation between public trust in central government (T1) and the public trust in city government (T2) $(\mathrm{r}=0.614, \mathrm{p}<0.01)$, which could be explained that citizens whom trust central government, due to this high correlation they apparently trust the city government as well as the central government.

\section{The Impact of Research Variables for Predicting the Probabilities of Public Trust in Government}

For examine the impact of the independent variables for predicting the probabilities of public trust in government, we did ordinal regression analyses, the results came out of the regression indicated that citizen satisfaction with the quality of public services (Fp1) and public trust in central government (T1) is statistical significant with $P$ value $(\mathrm{p}<0.001)$. Meanwhile, (FP1) with (T2) public trust in city government was not statistically significant, in another words that's means citizen satisfaction with public services can't be for predicting the probability of public trust in city government. Meanwhile the citizen satisfaction with government efforts against corruption is statically significant with both level of trust in central and city government (T1) (T2) with P values $(\mathrm{p}<0.05)$, $(\mathrm{p}<0.001)$ respectively. The results pointed out that citizen satisfaction with the transparency of government (FT3) is statically significant with public trust in central government (T1) with $(\mathrm{p}<0.001)$ has higher predicting probability comparing to citizen satisfaction with the transparency of the government (FT3) with public trust in city government (T2) as shown in Table 3.

To investigate the essential impact of the factors mentioned earlier on public trust, we computed the probability of showing strong trust in government at both the central level and local level, against or strongly against trust in government at both the central level and city level. This was done for different levels of public trust, while controlling for other variables at the sampling means. The 
Table 3. Ordinal regression results predicting trust in government.

\begin{tabular}{ccc}
\hline & Coefficient (SE) & \\
\hline Variable & $\begin{array}{c}\text { Trust in central } \\
\text { government (T1) }\end{array}$ & $\begin{array}{c}\text { Trust in city } \\
\text { government (T2) }\end{array}$ \\
\hline $\begin{array}{c}\text { Quality of public services (FP1) } \\
\text { Government efforts against } \\
\text { corruption (FC2) }\end{array}$ & $0.608(0.000)^{* * * *}$ & $0.205(0.240)$ \\
Government transparency (FT3) & $0.392(0.014)^{*}$ & $0.664(0.000)^{* * *}$ \\
Adjusted $R^{2}$ & $0.833(0.000)^{* * *}$ & $0.410(0.012)^{*}$ \\
Prob. Chi square & 0.441 & 0.289 \\
\hline
\end{tabular}

Notes: Significance: ${ }^{* *} \mathrm{p}<0.001 ;{ }^{* *} \mathrm{p}<0.01 ;{ }^{*} \mathrm{p}<0.05$. All tests are two-tailed tests.

predicted probabilities for trust in government are shown in Table 4. The results demonstrated that each independent variable regarding satisfaction with the quality of public services, with government effort against corruption, and the transparency of government had an essential impact on trust in government at both the city and central level. They were also all statistically significant. For example, the probability of expressing or strongly expressing trust in central government increased from $64.7 \%$ proportionally with the increase in the satisfaction with public services provided by the government. By contrast, the probability of expressing or strongly expressing trust in the city government with a high satisfaction in public services was about $55 \%$. This could be considered a little bit lower by $9.5 \%$ compared to the probability for predicting public trust in the central government through satisfaction with public services.

However, the predicted probabilities for trust in government at both levels can be predicted through another independent variable. This is the satisfaction with government efforts against corruption (FC2) about 59\%. This indicates that high satisfaction (FC2) is associated with high public trust in central government (T1), and predicts probability for trust in city government (T2) through the satisfaction with government efforts against corruption (FC2) which is about $66 \%$ and much higher than the predicted probability for central government by $7 \%$. We also examined the predicated probabilities for trust in government (T1), (T2) through the third independent variable, satisfaction with government transparency (FT3) with a predicted value of about $69 \%$ and $60 \%$ respectively.

\section{The Effect of Demographic Features on Trust in Government}

In the literature review many scholars studied the impact that demographic features had on trust in government in many different countries. However, no papers have examined the effect of demographic features on trust in government for Arabic countries-especially Yemen. Therefore, we examined the impact of the demographic features on trust in the Yemeni Government. Our study finds that there are variances surrounding demographic features which impact trust in 
Table 4. Predicted probabilities for trust in government by major independent variables.

\begin{tabular}{ccccc}
\hline & \multicolumn{2}{c}{ Trust in central government } & \multicolumn{2}{c}{ Trust in city government } \\
\hline Variable & $\begin{array}{c}\text { Strongly } \\
\text { trust it }\end{array}$ & $\begin{array}{c}\text { Strongly dis } \\
\text { trust it }\end{array}$ & $\begin{array}{c}\text { Strongly } \\
\text { trust it }\end{array}$ & $\begin{array}{c}\text { Strongly } \\
\text { dis trust it }\end{array}$ \\
\hline $\begin{array}{c}\text { Quality of public } \\
\text { services (FP1) }\end{array}$ & 0.647 & 0.352 & 0.55 & 0.449 \\
$\begin{array}{c}\text { Government efforts } \\
\text { against corruption } \\
\text { (FC2) }\end{array}$ & 0.596 & 0.40 & 0.66 & 0.34 \\
$\begin{array}{c}\text { The transparency of } \\
\text { the government } \\
\text { (FT3) }\end{array}$ & 0.696 & 0.30 & 0.601 & 0.398 \\
\hline
\end{tabular}

the Yemeni government and most of these demographic features are not associated with public trust in government at both the city level and central level. For example, only male respondents and respondents with middle school and below education showed a higher probability of trust in the government at city level with ( $\mathrm{p}<0.01),(\mathrm{p}<0.05)$ respectively. That means that public trust in city government through male respondents had a higher predicted probability by $63.7 \%$ than females at $36.2 \%$ for public trust in city government. Meanwhile, the predicted probability for public trust in city government for respondents who had education levels of middle school or below was $69.9 \%$ compared to other education levels for Yemeni respondents. Furthermore, the study also found that income level was not associated with public trust at both central and city government levels. In other words, public trust in central and city Yemeni government cannot be predicted by the income level of Yemeni citizens. However, the study did not find a significant relationship between gender, age, education or income level and trust in the central government. The results in Table 5 show that demographic variables had a much greater impact on trust in the city government than trust in the central government.

\section{Discussion}

This study finds that scores for citizen trust in government at the city and central levels in Yemen were much lower than expected for both levels of trust in local and central government. In addition, the percentage of respondents expressing or strongly expressing trust in government at central level was much lower than the percentage of respondents expressing the same perception at the city level $(1 \%)$ and $(2.6 \%)$ respectively. Meanwhile, results showed huge lack of trust in city and central Yemeni government. Here, the percentage of respondents who did not trust was about (61.7\%) towards the central government. This percentage is higher for city government $(68.1 \%)$ and maybe these results could be considered very obvious. This is because citizens have more interaction with local government than the central government. This result is similar to the literature found on Western countries [38]. 
Table 5. Effect of demographic features on trust in government.

\begin{tabular}{|c|c|c|c|}
\hline & \multirow[b]{2}{*}{ Variable } & \multicolumn{2}{|c|}{ Coefficient (SE) } \\
\hline & & Trust in central & \\
\hline \multirow{2}{*}{ Gender } & Male & $0.377(0.06)$ & $0.566(0.009)^{\star *}$ \\
\hline & Female & $-0.377^{\mathrm{a}}$ & $-0.566^{\mathrm{a}}$ \\
\hline \multirow{3}{*}{$\begin{array}{c}\text { Age } \\
\text { (years) }\end{array}$} & $18-29$ & $-0.723(0.093)$ & $-0.460(0.631)$ \\
\hline & $30-49$ & $-0.539(0.220)$ & $-0.504(0.604)$ \\
\hline & $50-65$ & $1.262^{\mathrm{a}}$ & $0.91^{\mathrm{a}}$ \\
\hline \multirow{4}{*}{ Education } & $\begin{array}{l}\text { Middle school and } \\
\text { below }\end{array}$ & $0.358(0340)$ & $0.847(0.025)^{\star}$ \\
\hline & High school & $0.246(0.347)$ & $0.455(0.098)$ \\
\hline & Junior collage & $0.321(0.258)$ & $0.545(0.068)$ \\
\hline & $\begin{array}{l}\text { Bachelor degree and } \\
\text { above }\end{array}$ & $-0.925^{\mathrm{a}}$ & $-1.847^{\mathrm{a}}$ \\
\hline \multirow{7}{*}{$\begin{array}{l}\text { Income } \\
\text { (Dollars) }\end{array}$} & Zero - 149.99 & $-0.048(0.885)$ & $-0.226(0.516)$ \\
\hline & $150-299.99$ & $-0.022(0.959)$ & $-0.225(0.616)$ \\
\hline & $300-449.99$ & $-0.212(0.630)$ & $-0.607(0.210)$ \\
\hline & $450-600$ & $-0.633(0.354)$ & $-.290(0.667)$ \\
\hline & $600-749.99$ & $-0.267(0.766)$ & $-0.307(0.547)$ \\
\hline & $750-900$ & $1.182^{\mathrm{a}}$ & $1.655^{\mathrm{a}}$ \\
\hline & $R^{2}$ & 0.023 & 0.048 \\
\hline
\end{tabular}

Notes: Significance: ${ }^{* *} \mathrm{p}<0.001 ;{ }^{* *} \mathrm{p}<0.01 ;{ }^{\star} \mathrm{p}<0.05 . R^{2}$ : Nagelkerke R-Square. All tests are two-tailed tests, ${ }^{\mathrm{a}}$ : set to zero because this parameter is redundant.

In addition to confirming the three hypotheses, this study also found some surprising results regarding the relationship between citizen satisfaction with the quality of public services and trust in government. It also discovered relationships between satisfaction with government effort against corruption, and trust in government, as well as satisfaction with government transparency and trust in government. First, the variable "satisfaction with the quality of public services" showed a much more substantive impact on public trust in central government than for the city government. This was true despite the fact some other studies have argued the opposite because public services are mostly supplied by local governments in metropolitan areas [39]. An explanation can be found for this result due to the fact that Yemeni government is a transitional government funded by international countries-especially the Gulf countries-in order to provide high quality public services for citizens. Therefore, Yemeni citizens considered the central government responsible for funding the city government to provide public services. Second, the variable "satisfaction with the transparency of the government" showed the highest substantive impact on public trust in central government compared to other independent variables that this study examined. Therefore, we concluded that satisfaction with the transparency of government is the key factor in determining trust in a central government. 
Third, the variable "satisfaction with government efforts against corruption" showed the highest substantive impact on trust in the city government compared to the other variables. Therefore, for the Yemeni city government, increases in the effort to fight corruption are more important than increasing public services if the goal is to enhance public trust in the city government.

The results of this study showed that all the demographic variables were not significant determinants of public trust in the central government of Yemen. Several scholars have named "critical citizens" as people who are younger, more highly educated and better paid. According to this scholar [40] has also argued that long-term economic development creates critical citizens who have higher expectations for government performance. These people are also less respectful to government authority and increasingly ready to challenge the government. The finding that younger citizens with higher education and higher income have less trust in the central government is accordance with the literature on more developed countries [23] [40]. For a country like Yemen with low economic development and a high rate of literacy especially among girls and with about $60.7 \%$ of respondents of this study income level monthly is range between ( 0 199.99 \$), it be would seem to be very obvious that Yemeni citizens aren't critical citizens. Therefore, as the results concluded, the huge lack of trust in central and local Yemeni government is associated with the lack of citizen satisfaction in the three independent variables that this study has examined.

\section{Conclusions}

This research contributes to a better understanding of public trust in the government of Yemen. Primarily, it does so by being the first comprehensive quantitative survey on transitional government. In other words, it is the first ever quantitative survey to examine public trust towards the Yemeni government at both central and local levels. This paper could also be considered to be internationally unique in terms of public trust in government for countries under situations to Yemen, which, to this point, have mostly been descriptive rather than analytical. More specially, this study is the first to confirm the determinants in declining public trust in the government of Yemen.

This research has provided some unique reflections on practical implications especially for Arabic countries and other countries under civil war or in transitional periods. Public managers and policymakers in Yemen should pay full attention to the challenges posed by public trust in the government, especially at this time. This is because Yemen now has two governments fighting each other. If the legal government wants to win the war, it should win its citizen satisfaction first before even thinking about spending governmental budgets on buying weapons. It should also be noted that the Yemenis revolution of 11th of February 2011 was against the political leadership and government. It arose from citizens who, at that time, said they had had enough of poor government performance and leadership for 33 years. This is how thing got out of control and ended with civil war. If the Yemeni government doesn't want to repeat this mis- 
take again, particularly at this critical time, and if Yemeni citizens are not satisfied with their legal government, there is a high possibility they will support the other government. In this sense, they will follow the government which provides what they need. Under this scenario, it should be quite obvious the legal government will lose the war even if wins battles.

There are some important limitations to this study which should be noted. First, as this research is a cross-sectional survey, it cannot confirm whether trust in government has declined. It also cannot fully observe the extent of factors associated with public trust in government. Second, because the data used here are perceptual rather than objective, a more complete study requires additional objective measures. Third, this survey was limited to urban areas under the control of the transitional government. It is therefore unsuitable for the results of this research to be generalized for the whole of Yemen due to the fact that there are tremendous differences in patterns of economic and social development. For developing this research in the future, we will continuously update and repeat our survey, and complement the data in order to provide significant insights into trends and dynamics associated with public trust in the government of Yemen.

\section{References}

[1] Chen, X. and Shi, T. (2001) Media Effects on Political Confidence and Trust in the People's Republic of China in the Post-Tiananmen Period. East Asia, 19, 84-118. https://doi.org/10.1007/s12140-001-0011-3

[2] Fukuyama, F. (1995) Trust: The Social Virtues and the Creation of Prosperity. JSTOR.

[3] Orren, G. (1997) Fall from Grace: The Public's Loss of Faith in Government. In: Why People Don't Trust Government, 77-107.

[4] Christensen, T. and Lægreid, P. (2005) Trust in Government: The Relative Importance of Service Satisfaction, Political Factors, and Demography. Public Performance \& Management Review, 28, 487-511.

[5] O'Neill, O. (2006) Transparency and the Ethics of Communication. Proceedings-British Academy, Oxford University Press, Oxford.

[6] Bouckaert, G. and Van de Walle, S. (2003) Comparing Measures of Citizen Trust and User Satisfaction as Indicators of 'Good Governance': Difficulties in Linking Trust and Satisfaction Indicators. International Review of Administrative Sciences, 69, 329-343.

[7] Van Ryzin, G.G. (2004) Expectations, Performance, and Citizen Satisfaction with Urban Services. Journal of Policy Analysis and Management, 23, 433-448. https://doi.org/10.1002/pam.20020

[8] Tyler, T.R. (2004) Enhancing Police Legitimacy. The Annals of the American Academy of Political and Social Science, 593, 84-99. https://doi.org/10.1177/0002716203262627

[9] Anderson, M.R. (2010) Community Psychology, Political Efficacy, and Trust. Political Psychology, 31, 59-84. https://doi.org/10.1111/j.1467-9221.2009.00734.x

[10] Thomas, C.W. (1998) Maintaining and Restoring Public Trust in Government Agencies and Their Employees. Administration \& Society, 30, 166-193. https://doi.org/10.1177/0095399798302003

[11] Miller, A.H. and Listhaug, O. (1998) Policy Preferences and Political Distrust: A 
Comparison of Norway, Sweden and the United States. Scandinavian Political Studies, 21, 161-187. https://doi.org/10.1111/j.1467-9477.1998.tb00010.x

[12] Easton, D. (1965) A Systems Analysis of Political Life. Wiley.

[13] Mishler, W. and Rose, R. (1997) Trust, Distrust and Skepticism: Popular Evaluations of Civil and Political Institutions in Post-Communist Societies. The Journal of Politics, 59, 418-451. https://doi.org/10.1017/S0022381600053512

[14] Mishler, W. and Rose, R. (2005) What Are the Political Consequences of Trust? A Test of Cultural and Institutional Theories in Russia. Comparative Political Studies, 38, 1050-1078. https://doi.org/10.1177/0010414005278419

[15] Levi, M. and Stoker, L. (2000) Political Trust and Trustworthiness. Annual Review of Political Science, 3, 475-507. https://doi.org/10.1146/annurev.polisci.3.1.475

[16] Akinloye Akinboade, O., Chanceline Kinfack, E. and Putuma Mokwena, M. (2012) An Analysis of Citizen Satisfaction with Public Service Delivery in the Sedibeng District Municipality of South Africa. International Journal of Social Economics, 39, 182-199. https://doi.org/10.1108/03068291211199350

[17] Morgan, D.R. and Pelissero, J.P. (1979) Citizen Satisfaction with Local Public Services in a Southwestern State. Review of Regional Economics and Business, 4.

[18] Van de Walle, S. and Bouckaert, G. (2003) Public Service Performance and Trust in Government: The Problem of Causality. International Journal of Public Administration, 26, 891-913. https://doi.org/10.1081/PAD-120019352

[19] Citrin, J. and Green, D.P. (1986) Presidential Leadership and the Resurgence of Trust in Government. British Journal of Political Science, 16, 431-453. https://doi.org/10.1017/S0007123400004518

[20] Mishler, W. and Rose, R. (2001) What Are the Origins of Political Trust? Testing Institutional and Cultural Theories in Post-Communist Societies. Comparative Political Studies, 34, 30-62. https://doi.org/10.1177/0010414001034001002

[21] Campbell, A.L. (2003) How Policies Make Citizens: Senior Political Activism and the American Welfare State. Princeton University Press, Princeton. https://doi.org/10.1515/9781400841318

[22] Kampen, J.K., De Walle, S.V. and Bouckaert, G. (2006) Assessing the Relation between Satisfaction with Public Service Delivery and Trust in Government. The Impact of the Predisposition of Citizens toward Government on Evaluations of Its Performance. Public Performance \& Management Review, 29, 387-404.

[23] Kim, S. (2010) Public Trust in Government in Japan and South Korea: Does the Rise of Critical Citizens Matter? Public Administration Review, 70, 801-810. https://doi.org/10.1111/j.1540-6210.2010.02207.x

[24] Rockers, P.C., Kruk, M.E. and Laugesen, M.J. (2012) Perceptions of the Health System and Public Trust in Government in Low- and Middle-Income Countries: Evidence from the World Health Surveys. Journal of Health Politics, Policy and Law, 37, 405-437. https://doi.org/10.1215/03616878-1573076

[25] Wong, T.K.-Y., Hsiao, H.-H.M. and Wan, P.-S. (2009) Comparing Political Trust in Hong Kong and Taiwan: Levels, Determinants, and Implications. Japanese Journal of Political Science, 10, 147-174. https://doi.org/10.1017/S146810990900351X

[26] Piotrowski, S.J. and Van Ryzin, G.G. (2007) Citizen Attitudes toward Transparency in Local Government. The American Review of Public Administration, 37, 306-323. https://doi.org/10.1177/0275074006296777

[27] Pasquier, M. and Villeneuve, J.-P. (2007) Organizational Barriers to Transparency a Typology and Analysis of Organizational Behaviour Tending to Prevent or Restrict Access to Information. International Review of Administrative Sciences, 73, 147- 
162. https://doi.org/10.1177/0020852307075701

[28] Florini, A. (2007) The Right to Know: Transparency for an Open World. Columbia University Press, Columbia. https://doi.org/10.7312/flor14158

[29] Heald, D. (2006) Varieties of Transparency. Oxford University Press for the British Academy. https://doi.org/10.5871/bacad/9780197263839.003.0002

[30] Holzner, B. and Holzner, L. (2006) Transparency in Global Change: The Vanguard of the Open Society. University of Pittsburgh Pre, Pittsburgh.

[31] Prat, A. (2009) The More Closely We Are Watched, the Better We Behave? Oxford University Press, Oxford.

[32] Torres, L. (2005) Service Charters: Reshaping Trust in Government-The Case of Spain. Public Administration Review, 65, 687-699. https://doi.org/10.1111/j.1540-6210.2005.00498.x

[33] Klitgaard, R. (1988) Controlling Corruption. University of California Press, Oakland, California.

[34] Nye, J.S., Zelikow, P. and King, D.C. (1997) Why People Don't Trust Government. Harvard University Press, Cambridge, Massachusetts.

[35] Barker, T. and Carter, D.L. (1991) Police Deviance. Anderson Cincinnati, Cincinnati, Ohio.

[36] Rose-Ackerman, S. (1999) Political Corruption and Democracy. Connecticut Journal of International Law, 14, 363.

[37] Cattell, R.B. (1966) The Scree Test for the Number of Factors. Multivariate Behavioral Research, 1, 245-276. https://doi.org/10.1207/s15327906mbr0102_10

[38] Box, R.C. and Musso, J.A. (2004) Experiments with Local Federalism Secession and the Neighborhood Council Movement in Los Angeles. The American Review of Public Administration, 34, 259-276. https://doi.org/10.1177/0275074004267848

[39] Zhao, D. and Hu, W. (2015) Determinants of Public Trust in Government: Empirical Evidence from Urban China. International Review of Administrative Sciences, 0020852315582136. https://doi.org/10.1177/0020852315582136

[40] Norris, P. (1999) Critical Citizens: Global Support for Democratic Government. OUP, Oxford. https://doi.org/10.1093/0198295685.001.0001 


\section{Appendix}

Table 1S. Scale Items, and alpha for citizen satisfaction with the quality of public services $(\mathrm{N}=420)$.

Q. To what extent do you rate the overall satisfaction with the following ...? These questions is adopted from [16]

With scale $1=$ Extremely dissatisfied to $7=$ Extremely satisfied

Total items Cronbach's Alpha $=0.887$

P1. Public Education such as (public schools, public institutions)

P2. Public libraries

P3. Police protection

P4. Fire protection

P5. Public hospital

P6. Housing price

P7. Public Transportation

P8. Public parks and playgrounds

P9.Cleanliness of streets, sidewalks, garbage collection and road maintenance

Table 2S. Scale Items, and Alpha for Citizen Satisfaction with government effort in fighting corruption in $(\mathrm{N}=420)$.

Q. To what extent are you satisfied with your government efforts in fighting corruption in the following sectors... With scale $1=$ Extremely dissatisfied to $7=$ Extremely satisfied

Total items Cronbach's Alpha $=0.925$

C1. Education system

C2. Legal/Judicial system

C3. Medical services

C4. Police

C5. Public Media

Table 3S. Scale items, and alpha for citizen satisfaction with government transparency $(\mathrm{N}=420)$.

Q. Please indicate the extent to which you satisfied or dis satisfied with the following ...? These questions is adopted from [26]

With scale $1=$ Extremely dissatisfied to $7=$ Extremely satisfied

Total items Cronbach's Alpha $=0.886$

1. The ability to know about everything that government does

2. The ability to access to information about the government records of contracts, including the amount and who got the contracts

3. The ability to access to information about your country's budgets or financial statements

4. The ability to access to information about your city or town land use or planning documents

5. Government efforts to provide information about government performance through electronically services on government's Websites

6. With government information that disclose by the public media

(TV, radio, newspapers, social media) 
Table 4S. Results of factor analysis on the question items for public services $(\mathrm{N}=420)$.

\begin{tabular}{cccc}
\hline \multirow{2}{*}{ Variable } & \multicolumn{3}{c}{ Factors } \\
\cline { 2 - 4 } & Items & Fp1 & Fp2 \\
\hline & P1 & 0.741 & 0.064 \\
& P2 & 0.741 & -0.127 \\
Citizen satisfaction with the & P3 & 0.628 & -0.246 \\
quality of public services & P4 & 0.733 & -0.239 \\
(FP1) & P5 & 0.809 & -0.027 \\
& P6 & 0.766 & 0.468 \\
& P7 & 0.521 & 0.765 \\
Eignvalues & P8 & 0.776 & -0.184 \\
Cumulative Percent & & 0.762 & -0.268 \\
& P9 & 4.792 & 1.048 \\
\hline
\end{tabular}

1) Extraction method: Principal component analysis. 2) Rotation method: Varimax with Kaiser Normalization.

Table 5S. Results of factor analysis on the question items government effort against corruption on Table $5 \mathrm{~S}(\mathrm{~N}=420)$.

\begin{tabular}{|c|c|c|}
\hline \multirow{2}{*}{ Variable } & \multicolumn{2}{|c|}{ Factors } \\
\hline & Items & $\mathrm{Fc} 3$ \\
\hline \multirow{5}{*}{$\begin{array}{l}\text { Citizen satisfaction with the government } \\
\text { effort against corruption (FC2) }\end{array}$} & $\mathrm{C} 1$ & 0.876 \\
\hline & $\mathrm{C} 2$ & 0.9 \\
\hline & $\mathrm{C} 3$ & 0.914 \\
\hline & $\mathrm{C} 4$ & 0.849 \\
\hline & C5 & 0.861 \\
\hline Eignvalues & \multicolumn{2}{|c|}{3.87} \\
\hline Cumulative Percent & \multicolumn{2}{|c|}{77.488} \\
\hline
\end{tabular}

Table 6S. Result of factor analysis on question items government transparency on Table $6 \mathrm{~S}(\mathrm{~N}=420)$.

\begin{tabular}{ccc}
\hline \multirow{2}{*}{ Variable } & \multicolumn{2}{c}{ Factors } \\
\cline { 2 - 3 } & items & Ft4 \\
\hline Citizen satisfaction with the government & $\mathrm{T} 1$ & 0.811 \\
transparency (FT3) & $\mathrm{T} 2$ & 0.848 \\
& $\mathrm{~T} 3$ & 0.824 \\
Eignvalues & $\mathrm{T} 4$ & 0.838 \\
Cumulative Percent & $\mathrm{T} 5$ & 0.747 \\
& $\mathrm{~T} 6$ & 0.788 \\
\hline
\end{tabular}


Submit or recommend next manuscript to SCIRP and we will provide best service for you:

Accepting pre-submission inquiries through Email, Facebook, LinkedIn, Twitter, etc. A wide selection of journals (inclusive of 9 subjects, more than 200 journals)

Providing 24-hour high-quality service

User-friendly online submission system

Fair and swift peer-review system

Efficient typesetting and proofreading procedure

Display of the result of downloads and visits, as well as the number of cited articles Maximum dissemination of your research work

Submit your manuscript at: http://papersubmission.scirp.org/

Or contact ojbm@scirp.org 